\title{
Protodrilidae (Annelida: Polychaeta) from the Hawaiian Islands and Comparison with Specimens from French Polynesia ${ }^{1}$
}

\author{
Fulie H. Bailey-Brock, ${ }^{2,5}$ Claude Fouin-Toulmond, ${ }^{3}$ and Richard E. Brock ${ }^{4}$
}

\begin{abstract}
Three species of Protodrilidae were collected from the islands of O'ahu and Ni'ihau in the Hawaiian chain, including specimens closely resembling Parenterodrilus taenioides (Jouin, 1979), described from Mo'orea (French Polynesia). Others are probably an undescribed species of Parenterodrilus that was found in fine sand substrate collected off Wai'anae, $\mathrm{O}^{\prime}$ ahu. A third species, Protodrilus albicans Jouin, 1970, described from Banyuls-sur-Mer (Mediterranean Sea) and recorded from Mo'orea and Tahiti as well, was also collected from O'ahu. Depths and habitat characteristics are given for these new records to the Hawaiian fauna. It is suggested that the wide geographical distribution of the different "cosmopolitan species" of Protodrilidae is related both to the dispersal by free-swimming larvae and to the ancient origin of this interstitial fauna.
\end{abstract}

Protodrilidae have long been considered a family of "Archiannelida" due to their small size, ventral ciliary gliding, ventral pharyngeal organ, and lack of conspicuous external segmental structures. Interstitial polychaetes previously called "archiannelids" are now regarded as specialized as opposed to primitive from an evolutionary perspective for Protodrilidae, Protodriloididae, Saccocirridae, Polygordiidae, Nerillidae, Dinophilidae, and Diurodrilidae (Westheide 1985, Purschke and Jouin-Toulmond 1988, Bailey-Brock 1999, Bailey-Brock et al. 2003).

Protodrilidae have well-developed sensory

${ }^{1}$ Funding for J.H.B.-B. and R.E.B. provided in part by the U.S. Environmental Protection Agency, Environmental Monitoring and Assessment Program for the Hawaiian Islands, 2002-2004. Manuscript accepted 21 August 2009.

${ }^{2}$ Zoology Department, University of Hawai'i at Mānoa, 2538 McCarthy Mall, Honolulu, Hawai'i 96822.

${ }^{3}$ Université Pierre et Marie Curie-Paris 6, CNRSUMR 7144 AD2M Station Biologique, BP 7429682 Roscoff Cedex, France.

${ }^{4}$ Water Resources Research Center, University of Hawai'i at Mānoa, Honolulu, Hawai'i 96822.

${ }^{5}$ Corresponding author.

Pacific Science (2010), vol. 64, no. 3:463-472

doi: $10.2984 / 64.3 .463$

(C) 2010 by University of Hawai'i Press

All rights reserved structures (Purschke 1990a,b,c, 1993), epidermal glands, epidermal ciliation, and a medioventral ciliary field. In Protodrilidae, Parenterodrilus Jouin, 1992 (Astomus is a synonym), living in coral sands, is unique in having a vestigial nonfunctioning gut, no mouth, no symbiotic bacteria, and a peculiar body shape (Jouin 1979). The ultrastructure of the cephalic sense organs and central nervous system demonstrates the sister-group relationship to Protodrilus and the derived position of Parenterodrilus (Purschke and JouinToulmond 1993, 1994).

The ultrastructure of the ciliated epidermis suggests transepidermal absorption of nutrients (Jouin 1992). Experiments made on living animals, with ferritin added to the seawater in contact with the animals, demonstrated that after $30 \mathrm{~min}$ the epidermis has few subcuticular coated vesicles containing ferritin, this substance being already concentrated in endosomes in the apical part of epidermal cells and in secondary lysosomes more basally (Jouin-Toulmond 1994).

The males of Parenterodrilus taenioides (Jouin 1979), like Protodrilus species, have lateral organs and sperm ducts, and the ultrastructure of the spermatozoa is basically the same in the two genera (Jouin-Toulmond and Purschke 2004). Adaptations that facilitate reproduction in Protodrilus include transfer of sperm by spermatophores deposited in 
the external milieu and then collected by the female epidermis and internal fertilization (Jägersten 1952, Jouin 1970, von Nordheim 1989, 1991a,b, Purschke 2006). The eggs are spawned and attached on sand grains; the larvae have a pelagic life, and metamorphosis depends on the availability of suitable habitat substratum (Jägersten 1952).

Previous records from the Hawaiian Islands include Protodrilus sp. (Bailey-Brock 1987) from the southeast shore of O'ahu. In this paper, we discuss Protodrilus spp. that were collected on O'ahu from sewage outfall sites and live specimens from Kawainui Beach Park that were examined briefly in the laboratory but did not survive in aerated shallow containers of sand. Collections of coral sands and reef rubble were made during an extensive coastal Estuarine Monitoring Program (EMAP) initiated by the U.S. Environmental Protection Agency. For comparison, previously unpublished data on specimens collected in French Polynesia (by C.J.-T.) are presented.

\section{MATERIALS AND METHODS}

Sand cores (11 cm diameter, $5 \mathrm{~cm}$ deep) were collected by divers, fixed in $10 \%$ formalin for $24 \mathrm{hr}$ or longer and elutriated over $0.5 \mathrm{~mm}$ and $0.25 \mathrm{~mm}$ sieves to extract the infauna. Protodrilids and other polychaetes were retained on the sieves and transferred to ethanol for storage. Parenterodrilus specimens were placed on slides with two drops of glycerol and examined microscopically. Protodrilus specimens were stained with Carmalum and mounted in gelatin-glycerol or in Canada balsam after dehydration. Illustrations were made with the aid of a compound microscope and drawing tube. Only fixed, unrelaxed specimens of Hawaiian material were examined.

Hawaiian localities where sand cores containing protodrilids were collected by divers

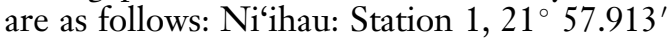
$\mathrm{N}, 160^{\circ} 7.428^{\prime} \mathrm{W}$, located in Keawanui Bay just seaward of a sand beach on the northwestern section of the coast of $\mathrm{Ni}$ 'ihau (sediment comprised $50 \%-60 \%$ carbonate sands of medium grain size), collected by EMAP divers on 18 June 2002, at $4.85 \mathrm{~m}$ depth. O'ahu: Two sites were investigated: (1) sewage outfall monitoring stations at Wai'anae, off the west coast of O'ahu (sediments comprised medium- to fine-grain carbonate sands), sampled 7-9 June 2004 at depths of 27-33.5 m; (2) Kūhiō Beach, part of an extensive sand beach at Waikiki on the south coast of $\mathrm{O}^{\prime}$ ahu (clean medium- to fine-grain sands), collected 12 October 2006 and February 2007 at $5 \mathrm{~m}$ depth.

In French Polynesia, live mature specimens of Protodrilus albicans were collected in coarse sand near the water's edge of beaches in Mo'orea (Irioa) and Tahiti (Vairao). They were examined for reproduction: spermatophores, sperm transfer, spawning, and young larvae were observed microscopically in Mo'orea in July 1981.

Specimens studied have been deposited in the Muséum National d'Histoire Naturelle (MNHN) and in J.B.-B.'s personal collection at the University of Hawai'i.

\section{RESULTS}

\section{Parenterodrilus taenioides (Jouin, 1979)} Figure 1

Astomus taenioides Jouin, 1979:2448.

Parenterodrilus taenioides. -Jouin, 1992:1833.

material examined. Hawai'i, Ni'ihau: Four specimens collected from Keawanui Bay, $4.85 \mathrm{~m}$ depth, June 2002, sediment comprised $50 \%-60 \%$ medium-grain carbonate sands; O'ahu: two specimens collected at Waikìkī, Kūhiō Beach, clean medium- to fine-grain sands, $5 \mathrm{~m}$ depth, collected in October 2006. Prepared slides of specimens in J.B.-B.'s personal collection at the University of Hawai $i$.

MORPHOLOGY. The fixed and unrelaxed Hawaiian specimens measure about $6.5 \mathrm{~mm}$ long and $0.15 \mathrm{~mm}$ wide and are dorsoventrally flattened and distinctly annulated at the segment borders (Figure 1A,D,E). The anterior region has a pair of palps that are terminal in position, possess canals, and are covered with cilia (Figure $1 B, C$ ). The brain appears as an internal dense area just behind 


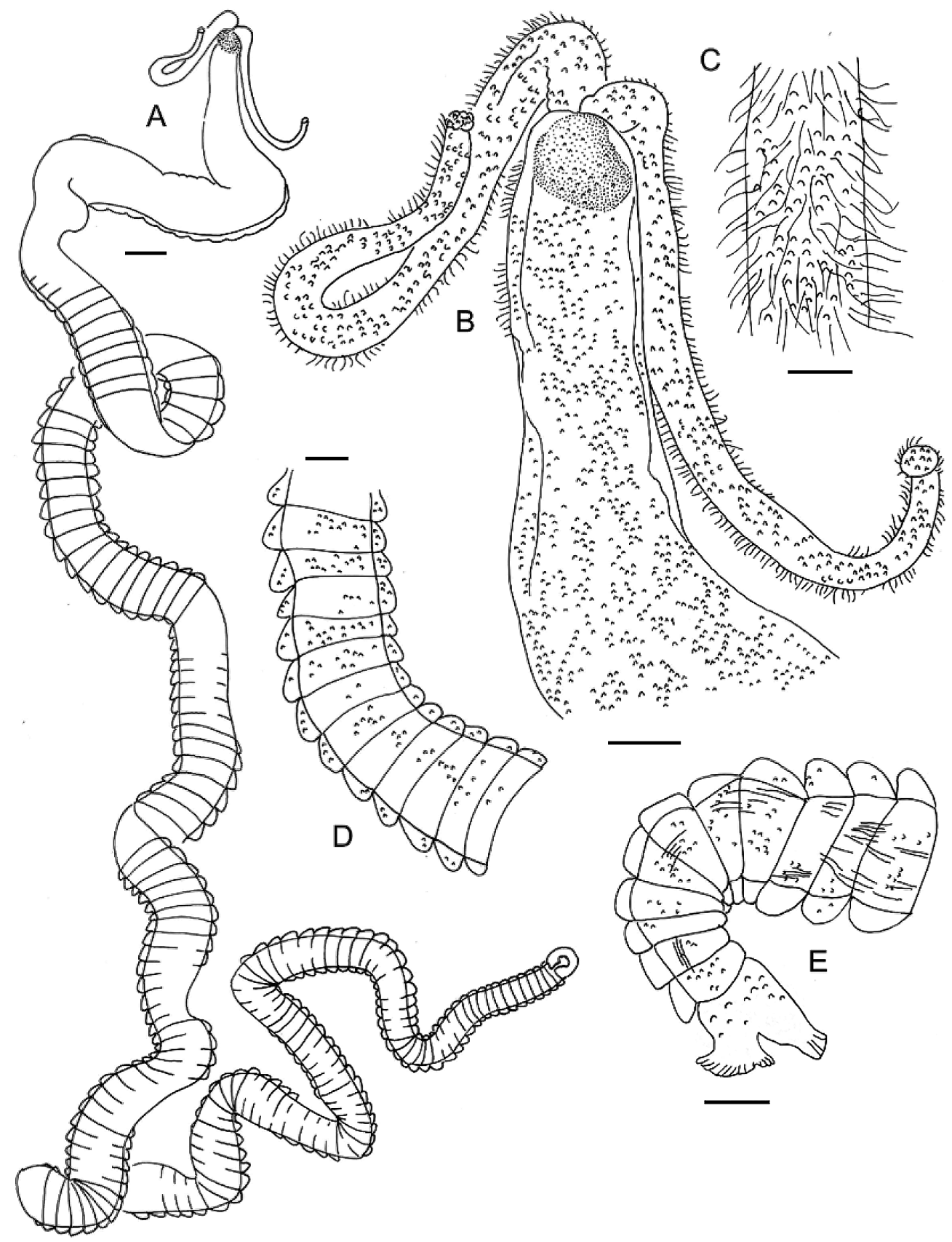

Figure 1. Parenterodrilus taenioides, specimen from Nicihau (Hawai'i). $A$, Entire specimen; $B$, anterior region; $C$, part of a palp showing cilia; $D$, segments from midbody region; $E$, posterior end with pygidium. Note lobes with ducts of adhesive gland cells. Scale bars: $A, 100 \mu \mathrm{m} ; B, D, E, 50 \mu \mathrm{m} ; C, 10 \mu \mathrm{m}$. 
the base of the palps. Longitudinal muscles are more evident in the posterior region, which has two flaring pygidial lobes with adhesive glands (Figure $1 E$ ). The salivary glands could not be detected on fixed specimens. In the Polynesian specimens they were found only on ultrastructural sections (Jouin 1992).

The specimens were immature when collected in June. Comparison of the characteristics of the Hawaiian male specimens with those of specimens from Mo'orea would be useful. Females are unknown.

remarks. Parenterodrilus taenioides was described from specimens collected in coral sands (about $1.5 \mathrm{~m}$ deep) at Mo'orea, French Polynesia. This is the first record of the species at another locality. It is a Pacific species, probably restricted to sublittoral coral sands near coral colonies, where the species can thrive due to the presence of abundant dissolved and particulate organic matter in those areas. The new collection sites off $\mathrm{Ni}^{\text {'ihau }}$ (4.85 m depth) and Kūhiō Beach on O'ahu (5 $\mathrm{m}$ depth) are adjacent to extensive shallow coral reefs and are deeper than the type locality.

Nutrition in $P$. taenioides is not fully understood. Jouin (1992) established that the vestigial gut contained intracellular unidentified crystals and suggested a bioaccumulation role for this residual organ. Symbiotic bacteria were not detected in the cuticle, epidermis, or vestigial gut, and transport of particulate or dissolved organic matter through the epidermal cells (transepidermal $=$ parenteral absorption) is most likely the means of organic uptake (Jouin 1992, Jouin-Toulmond 1994). This is unusual for a free-living adult annelid and unique to this genus, which is otherwise similar in morphological features to other protodrilids. The residual gut is reduced to a thin canal with a very narrow ciliated lumen. The salivary glands (detected with electron microscopy) are present in some anterior body segments, as in Protodrilus species, but in $P$. taenioides the secretion is released at the epidermal ventral surface of the prostomium (Jouin 1992).

A few sexually mature male specimens were examined in February 1991 in Mo'orea. The males of P. taenioides, like those of Proto- drilus species, have lateral organs and sperm ducts, and the ultrastructure of the spermatozoa is essentially the same in the two genera (Jouin-Toulmond and Purschke 2004). Females are still unknown, but it is likely that the species has a planktonic larva like Protodrilus species. This could explain the current geographical extension of the species through the Pacific Ocean (Mo'orea in French Polynesia and the Hawaiian Islands).

\section{Parenterodrilus sp.}

Figure 2

MATERIAL EXAMined. Hawai'i, O'ahu: West coast: One immature specimen collected from sand substrate off Wai'anae, June 2004, at depths of 27-33.5 m, sediments comprised medium- to fine-grain carbonate sands. Specimen in J.B.-B.'s personal collection at the University of Hawai'i.

MORPHOLOGY. Only one immature specimen was collected. Key feature is the dorsoventrally flattened body, wider than $P$. taenioides (about $3 \mathrm{~mm}$ long and $0.26 \mathrm{~mm}$ wide in this fixed unrelaxed specimen). The other characters (segmentation, ciliated cephalic palps [Figure $2 A, B, C, D$ ], two-lobed pygidium [Figure $2 E$ ], and absence of a mouth and functional gut) are similar to those of the type species, P. taenioides. Comparison of the characteristics of Hawaiian specimens, especially the male specimens, with those of specimens from Mo'orea would be useful.

\section{Protodrilus albicans Jouin, 1970}

Figures 3, 4

MATERIAL EXAmined. Hawai'i, O'ahu: Kūhiō Beach, Waikīkī, nine specimens, collected 12 October 2006. Clean medium- to fine-grain sands were collected as part of a beach nourishment study. Specimens deposited in MNHN (reference collection number PNT 11, one male and one female); mature specimens also in J.B.-B.'s personal collection.

France: Mediterranean, Banyuls-sur-mer (type locality), coarse sand near the water's edge of Le Troc beach. 


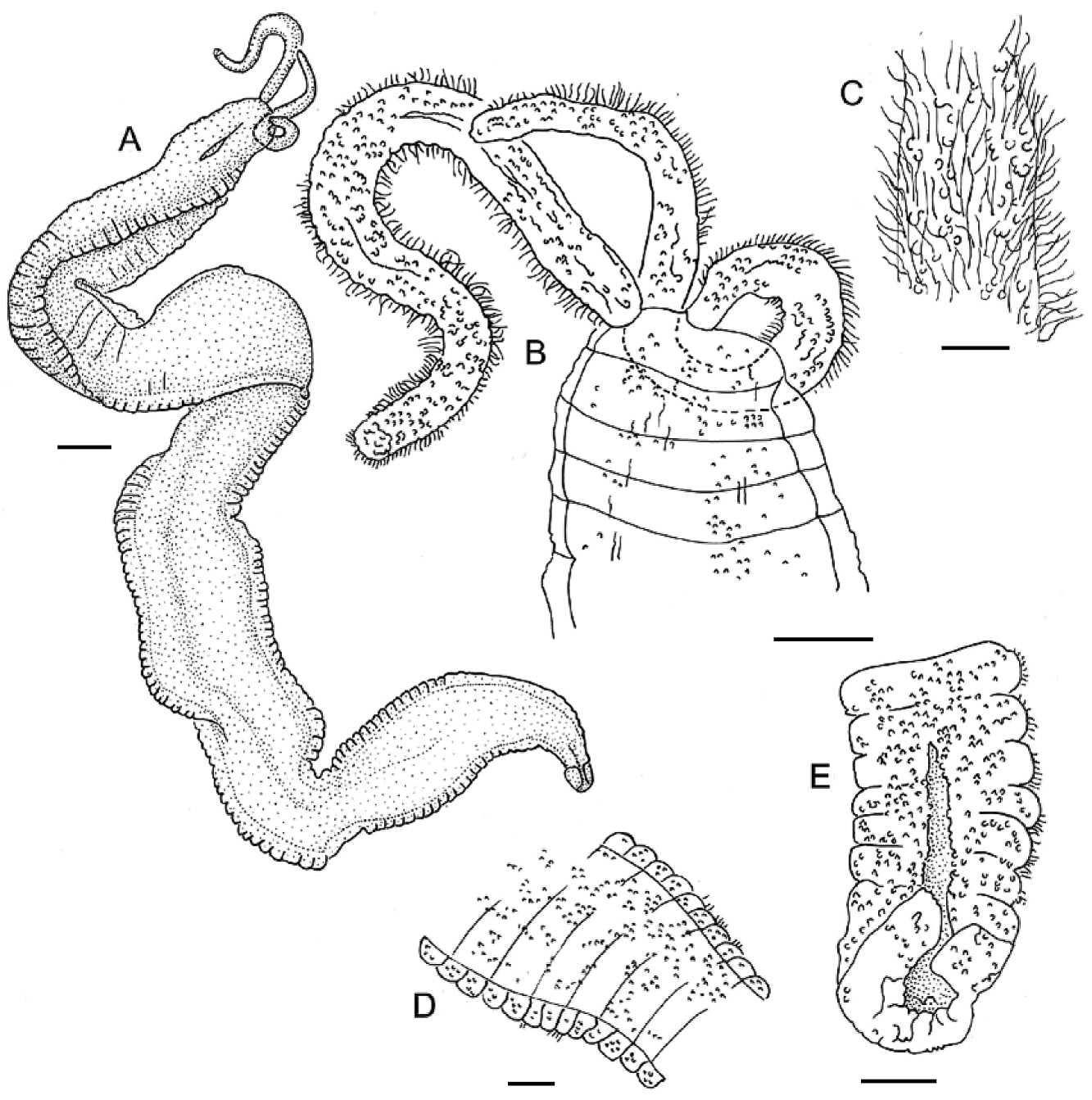

Figure 2. Parenterodrilus sp., specimen from west coast of $\mathrm{O}^{6} \mathrm{ahu}$ (Hawai'i). $A$, Entire specimen; $B$, anterior region; $C$, part of a palp showing cilia; $D$, segments of midbody region; $E$, posterior end with pygidial lobes turned down ventrally. Scale bars: $A, 100 \mu \mathrm{m} ; B, D, E, 50 \mu \mathrm{m} ; C, 10 \mu \mathrm{m}$.

French Polynesia: island of Mo'orea, coarse sand near the water's edge of beaches, east part of Irioa; island of Tahiti at Vairao. Specimens deposited in MNHN (reference collection number PNT 12, two males and one female). Specimens on slides prepared by C.J.-T. also in J.B.-B.'s personal collection.

Morphology. The morphology and white color of the preserved Hawaiian specimens are similar to those of the Mediterranean specimens, but the Hawaiian specimens are smaller: up to 50 segments in the longest specimens, $9 \mathrm{~mm}$ long and $0.22 \mathrm{~mm}$ wide. The shape and position of the three pairs of prostomial sensory organs are the same as in the Mediterranean specimens: in the most anterior part of prostomium, two unpigmented ocelli that were previously called "statocysts" (see Purschke 1990c) located near each other; two long $(800 \mu \mathrm{m})$ ciliated palps reaching, when oriented posteriorly, the level of segment four; and more posteriorly on the pro- 

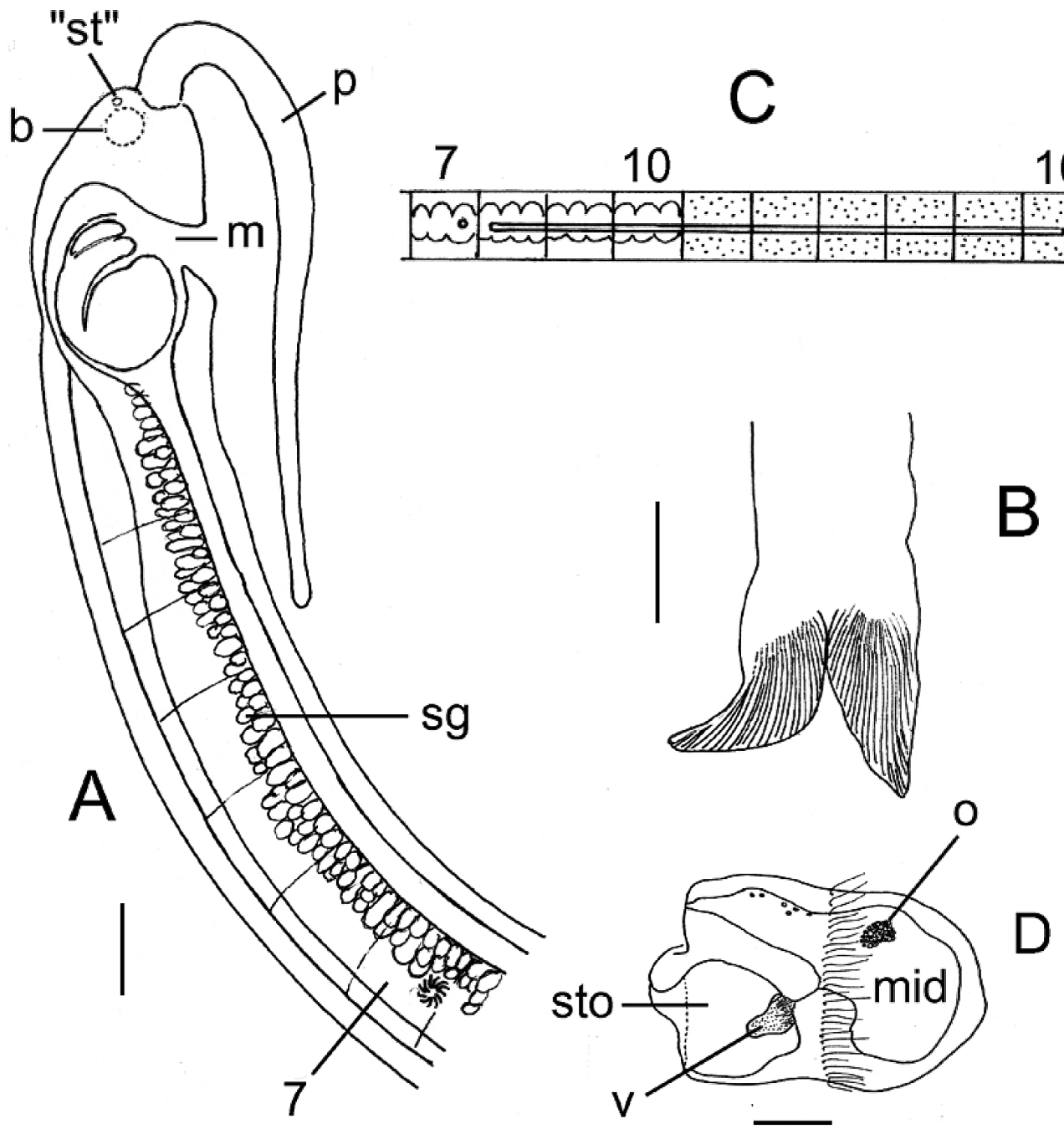

Figure 3. Protodrilus albicans. $A-C$ : Specimen from Kūhiō Beach (Hawai'i). $A$, Anterior part of a fixed male, profile view (ciliation not represented); $B$, posterior part of body with pygidial lobes and ducts of adhesive gland cells; $C$, diagram of a male showing localization of salivary glands up to segment 10, of gonads from segment 12, and of lateral organs in segments 7 to 16. $D$ : Specimen from Mo'orea, lateral view of a trochophore larva. b, brain; m, mouth; mid, midgut; o, ocellus; p, palp; sg, salivary glands; "st," unpigmented ocellus (so-called "statocyst"); sto, stomodeum; v, valvula. Scale bars: $A, 100 \mu \mathrm{m} ; B, 50 \mu \mathrm{m} ; D, 10 \mu \mathrm{m}$.

stomium two well-developed dorsal ciliated nuchal organs not easily observed on these fixed specimens. Epidermal glands are abundant all along the body, but the "bacillary glands" as well as the general body ciliation, both easily seen in living animals, are more difficult to identify on fixed specimens. Pygidium with two well-developed adhesive lobes
(Figure $3 B$ ). Along the esophagus, salivary glands are present in the first nine to 10 body segments (Figure 3A,C).

Sexually mature specimens: All specimens collected in October 2006 were sexually mature. As in other species of Protodrilus, the gonads are present in segments following the anterior ones that contain the salivary glands. 


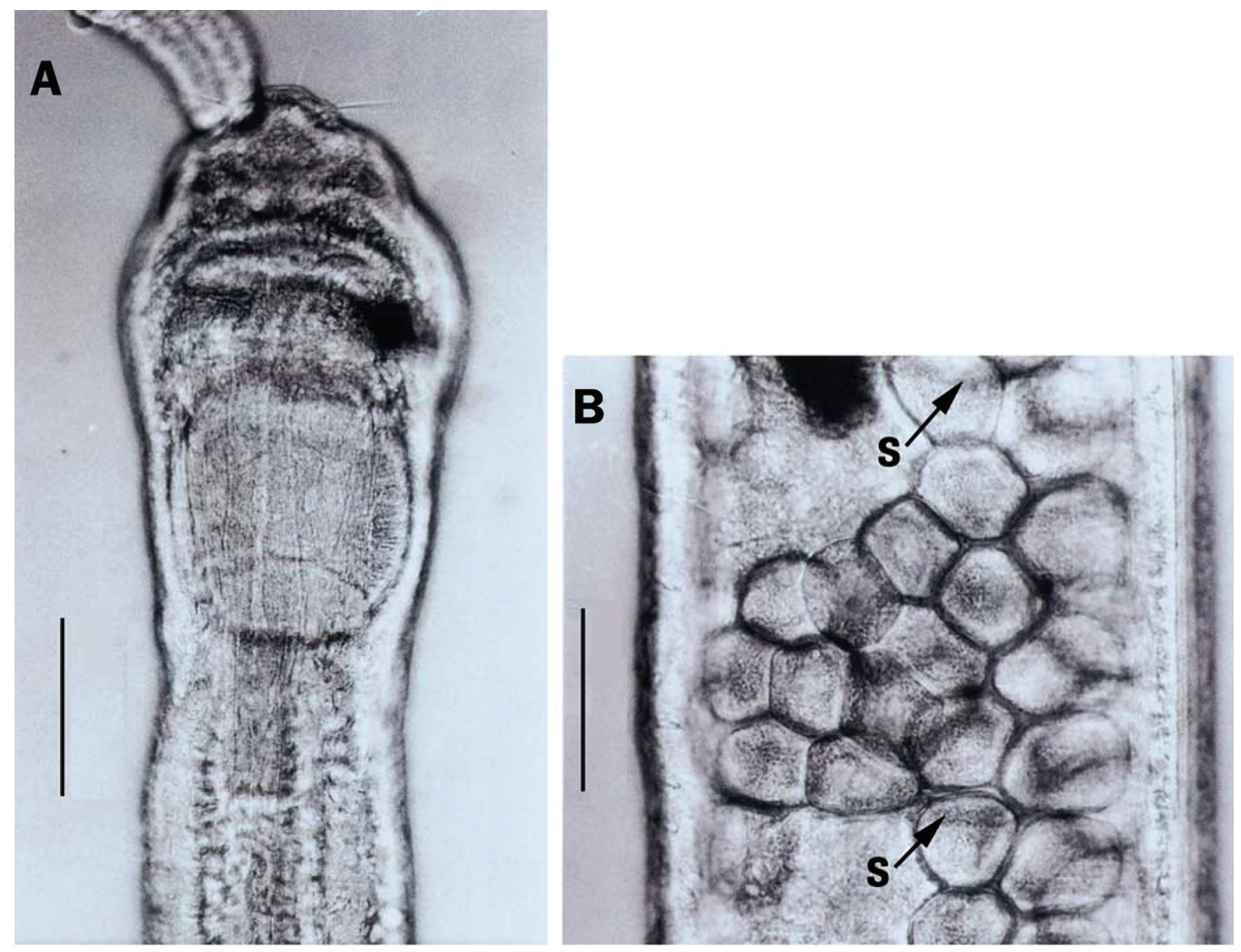

Figure 4. Protodrilus albicans, photomicrographs of a live mature female specimen from Vairao (Tahiti). $A$, Dorsal view of head (one palp missing), peristomium with muscular pharyngeal organ, and first two body segments; $B$, lateral view of a fertile segment, showing the right coelomic cavity, limited by 2 septa (s), containing numerous small mature oocytes. Scale bars: $A, 100 \mu \mathrm{m} ; B, 50 \mu \mathrm{m}$.

In the females the gonads extend, on both sides of the digestive tract, all along the body from segments 11 or 12 posteriorly, except in the three to five prepygidial segments. In each mature segment there is a large number (40-60) of small mature oocytes (about 35 $\mu \mathrm{m}$ in diameter).

In the males the gonads extend as in the females from segment 11 or 12 posteriorly; paired lateral organs are present in segment seven (as a pair of small, round glandular dimples), and from segment eight to 16 as paired continuous ciliated lateral grooves (Figure 3C); the sperm ducts could not be observed on these fixed specimens. The general morphology and the reproductive characters of the sexually mature specimens, which are good specific characters in the genus Protodrilus, are similar in the Hawaiian and Mediterranean specimens.

COMPARISONS. The specimens collected from the islands of Mo'orea and Tahiti, French Polynesia, were sexually mature in July 1981. These specimens (Figure 4) are smaller than the Mediterranean ones: the total number of segments ranges from 33 to 43 , and they are $6-7 \mathrm{~mm}$ in length and $0.16 \mathrm{~mm}$ wide. In the anterior part of the prostomium, the Polynesian specimens have two pigmented ocelli on the external border of each "statocyst." Such pigmented ocelli are absent in both the Mediterranean and Hawaiian specimens. The other features, especially those of the mature specimens (fertile 
region extending from segment 11 to segment 30 or 40 , presence of numerous small oocytes in females [Figure 4B], and extent of lateral organs [segments seven to 16] and presence of four pairs of sperm ducts in males), are in accordance with the description of the Mediterranean specimens of $P$. albicans.

REPRODUCTION AND LARvaE. Male and female specimens from Banyuls-sur-mer and from Mo'orea kept isolated in laboratory conditions reproduced easily: several spermatophores deposited by the males on sand grains or on the substratum were taken up by the female epidermis. As in other Protodrilus species (Jägersten 1952), spermatozoa from spermatophores crossed the epidermis and body wall of the females, reaching the coelomic cavities. Then fertilized mature females spawned clusters of eggs that became attached to the substratum. Young swimming larvae appeared about $10 \mathrm{hr}$ later.

The hatching larvae, about $40 \mu \mathrm{m}$ long, had the same morphology in both the Banyuls and Mo'orea specimens. At this stage (Figure $3 D$ ), only one lateral pigmented ocellus and one ring of cilia forming the prototroch are present in the young larva; 1 to 2 days later, a second lateral ocellus and three other rings of cilia at the prototroch are formed. The foregut (stomodeum) is oriented posteriorly. A remarkable element of this larva is the "ameboid" valvula located in the foregut, at the connection with the midgut. A similar valvula was described for the first time in the larva of Protodrilus adhaerens ("ameboid protuberance") by Jägersten (1952). In several other Protodrilus species this valvula is composed of only a simple tuft of cilia. In $P$. albicans and $P$. adhaerens, cilia are also present, embedded in the mobile protuberance that allows swallowing of small food particles from the stomodeum into the midgut.

The similar size and number of coelomic mature oocytes in the Mediterranean, Polynesian, and Hawaiian specimens suggest a similar larval development for the Hawaiian specimens.

remarks. Protodrilus albicans was described from the Mediterranean. Populations of morphologically very similar specimens are present in the Hawaiian Islands (O'ahu, Kūhiō Beach) and have also been collected in Mo'orea (by C.J.-T.) in the same biotope as in Banyuls-sur-Mer (i.e., in coarse sand of beaches near the water's edge).

Most specific characters (general size and body shape, extent of salivary glands, extent of gonads and lateral organs in males, number and size of mature oocytes in each fertile segment of females) are similar in the Mediterranean, Polynesian, and Hawaiian specimens. Thus, for the time being, we consider the Mediterranean and Pacific populations of $P$. albicans as belonging to the same species. More detailed studies on live material, and ultrastructural and molecular studies on these different geographical populations will be necessary to detect possible differences at subspecies or species level.

\section{DISCUSSION}

Five Protodrilus species were collected in coral sands from Mo'orea and Tahiti by C.J.-T. Two are undescribed species, and three are very similar to European species: $P$. adhaerens Jägersten, 1952; $P$. bypoleucus Armenante, 1903; and P. albicans. These appear to be "cosmopolitan species" previously known from the Mediterranean (Naples, Banyulssur-mer) and the Northeast Atlantic (Gullmar Fjord, Channel, Roscoff) (Westheide 1990).

Colonization of new sites along shorelines could be accomplished by Protodrilus albicans with a peculiar behavior of the species (Jouin 1970): live specimens from Banyuls-sur-Mer were observed emerging from the sediment and swimming in the water above the sediment, an uncommon behavior in protodrilids, which generally stick on sand particles when disturbed. In addition, dispersal of the species can also occur by planktonic larval dispersion, a biological character common to all Protodrilus species (Jägersten 1952). In contrast, two species of the genus Protodriloides Jouin, 1966, have a direct benthic development: the large yolky eggs develop into juveniles in a cocoon attached to sand grains (Swedmark 1954, Jouin 1962). Colonization of new sites is then accomplished by dispersal of eggs in 
cocoons, or adults, attached to grains of sediment, as reported in the cosmopolitan species Protodriloides chaetifer (wrongly cited as Protodrilus chaetifer in Sterrer [1973]).

The current wide geographical distribution of the different "cosmopolitan species" of Protodrilus can be linked both to the dispersal by free-swimming larvae and to the ancient age of this interstitial fauna. Several authors (Sterrer 1973, Westheide 1977) have suggested that the interstitial fauna is very old, and, as such, Protodrilus albicans and other species of the genus found on coasts of the Northeast Atlantic, the North Sea, the Mediterranean Sea, and in Pacific island groups could be relict species of the Tethys Sea, which extended from the Caribbean to Indonesia via the Mediterranean during the Cenozoic, 65 million yr ago.

\section{ACKNOWLEDGMENTS}

We are most grateful to André Toulmond, Station Biologique Roscoff; Sue Monden, Zoology Department, University of Hawai' $i$, for the illustrations in Figures 1 and 2; and also to Xiufu Shuai, Water Resources Research Center, University of Hawai' $i$, for preparing the final illustrations in electronic format. We thank Alan Kam and the staff of the Wormlab, University of Hawai'i, for collecting, sorting, and preserving the specimens. Thanks also to B. Salvat and the staff of the Antenne MNHN and EPHE (École practique des Hautes Études) for facilities and in the collection of material for laboratory studies in Mo'orea (July 1973, July 1981, February 1991).

\section{Literature Cited}

Bailey-Brock, J. H. 1987. Phylum Annelida. Section 3, chapter 2. Pages 213-454 in D. M. Devaney and L. G. Eldredge, eds. Reef and shore fauna of Hawaii. Section 2. Platyhelminthes through Phoronida, and Section 3. Sipuncula through Annelida. Bernice P. Bishop Mus. Spec. Publ. 64 (2 and 3).

- 1999. Nerillidae of Hawai'i: Two new records of interstitial polychaetes. Pac. Sci. 53:299-304.

Bailey-Brock, J. H., J. Dreyer, and R. E. Brock. 2003. Three new species of Saccocirrus (Polychaeta: Saccocirridae) from Hawai'i. Pac. Sci. 57:463-478.

Jägersten, G. 1952. Studies on the morphology, larval development and biology of Protodrilus. Zool. Bidr. Upps. 29:425-515.

Jouin, C. 1962. Le développement larvaire de Protodrilus chaetifer Remane (Archiannélides). C. R. Acad. Sci. Paris 255:30653067.

. 1966. Morphologie et anatomie comparée de Protodrilus chaetifer Remane et Protodrilus symbioticus Giard; création du nouveau genre Protodriloides (Archiannélides). Cah. Biol. Mar. 7:139-155.

- 1970. Recherches sur les Protodrilidae (Archiannélides). I. Etude morphologique et systématique du genre Protodrilus. Cah. Biol. Mar. 11:367-434.

1979. Description of a free-living polychaete without gut: Astomus taenioides n. gen., n. sp. (Protodrilidae, Archiannelida). Can. J. Zool. 57:2448-2456.

1992. The ultrastructure of a gutless annelid Parenterodrilus gen. nov. taenioides (= Astomus taenioides) (Polychaeta, Protodrilidae). Can. J. Zool. 70:1833-1870.

Jouin-Toulmond, C. 1994. The ultrastructure of a gutless annelid Parenterodrilus G. N.. taenioides ( $=$ Astomus taenioides) (Polychaeta, Protodrilidae). In J.-C. Dauvin, L. Laubier, and D. J. Reish, eds. Actes de la 4ème Conférence internationale des Polychètes. Mem. Mus. Natl. Hist. Nat. 162:626-627. Jouin-Toulmond, C., and G. Purschke. 2004. Ultrastructure of the spermatozoa of $\mathrm{Pa}$ renterodrilus taenioides (Protodrilida: "Polychaeta") and its phylogenetic significance. Zoomorphology (Berl.) 123:139-146.

Nordheim, H. von. 1989. Vergleichende Ultrastrukturuntersuchungen der Euund Paraspermien von 13 Protodrilus arten (Polychaeta, Annelida) und ihre taxonomische und phylogenetische Bedeutung. Helgol. Meeresunters. 43:113-156.

. 1991a. Ultrastructure and functional morphology of male genital organs and spermatophore formation in Protodrilus 
(Polychaeta, Annelida). Zoomorphology (Berl.) 111:81-94.

1991b. Ultrastructure and functional morphology of the female reproductive organs in Protodrilus (Polychaeta, Annelida). Helgol. Meeresunters. 45:465-485.

Purschke, G. 1990a. Comparative electron microscopic investigations of the nuchal organs in Protodriloides, Protodrilus and Saccocirrus (Annelida, Polychaeta). Can. J. Zool. 68:325-338.

1990b. Fine structure of the so-called statocysts in Protodrilus adhaerens (Protodrilidae, Polychaeta). Zool. Anz. 224:286296.

. 1990c. Ultrastructure of the "statocysts" in Protodrilus species (Polychaeta): Reconstruction of the cellular organization with morphometric data from receptor cells. Zoomorphology (Berl.) 110: 91-104.

1993. Structure of the prostomial appendages and the central nervous system in the Protodrilida (Polychaeta). Zoomorphology (Berl.) 113:1-20.

. 2006. Problematic annelid groups. Pages 639-677 in G. Rouse and F. Pleijel, eds. Reproductive biology and phylogeny of Annelida. Science Publishers, Enfield, New Hampshire.

Purschke, G., and C. Jouin-Toulmond. 1988. Anatomy and ultrastructure of the ventral pharyngeal organ of Saccocirrus (Saccocirridae) and Protodriloides (Protodriloidae fam. n.) with remarks on the phylogenetic relationships within the Protodrilida
(Annelida: Polychaeta). J. Zool. (Lond.) 215:405-432.

_. 1993. Ultrastructure of presumed ocelli in Parenterodrilus taenioides (Polychaeta, Protodrilidae) and their phylogenetic significance. Acta Zool. 74 (3): $247-$ 256.

. 1994. Ultrastructure of sense organs and the central nervous system in Parenterodrilus taenioides and their phylogenetic significance in the taxon Protodrilida (Annelida, Polychaeta). In J.-C. Dauvin, L. Laubier, and D. J. Reish, eds. Actes de la 4ème Conférence internationale des Polychètes. Mem. Mus. Natl. Hist. Nat. 162:119-128.

Sterrer, W. 1973. Plate tectonics as a mechanism for dispersal and speciation in interstitial sand fauna. Neth. J. Sea Res. 7:200222.

Swedmark, B. 1954. Etude du développement larvaire et remarques sur la morphologie de Protodrilus symbioticus Giard (Archiannélides). Ark. Zool. 2, 6 (25): 511-522.

Westheide, W. 1977. The geographical distribution of interstitial polychaetes. Mikrofauna Meeresboden 61:287-302.

. 1985 . The systematic position of the Dinophilidae and the archiannelid problem. Pages 310-326 in S. Conway Morris, J. D. George, R. Gibson, and H. M. Platt, eds. The origin and relationships of lower invertebrates. Oxford University Press, Oxford.

1990. Polychaetes: Interstitial families. Synop. Br. Fauna New Ser. 44. 